\title{
The Effect of use of Humic Acid in Some Blood Parameters and Rumen Protozoa in Norduz Lambs
}

\author{
Cemal BUDA $\breve{G}^{1}$, Uğur KARA ${ }^{1}$
}

\begin{abstract}
This study investigated the effect of different levels of humic acid on some rumen and blood parameters and rumen protozoa in Norduz sheep. The study was designed and conducted in four-factor repeated measures analysis of variance. Totally 24 , approximately 16 -week old, female Norduz sheep were used in the study. Four feeding groups were designed. The first group was not given humic acid (C, control GI); the second group was given humic acid of $0.015 \%$ of the live weights of the sheep (GII); the third group was given humic acid of $0.030 \%$ of the live weights of the sheep (GIII); the fourth group was given humic acid of $0.060 \%$ of the live weights of the sheep (GIV). A total of eight sheep having similar ages and live weights were randomly distributed to each group (live weights of $40.230 \pm 1.25$ ). The feed consumed by the sheep was limited to $2.5 \%$ of their live weights. Blood and rumen fluid samples were collected 2 times (before the test and on $25^{\text {th }}$ day of the test). Comparison of some blood parameters were collected from the animals before and after the test revealed no significant difference in serum triglyceride and rumen $\mathrm{pH}$ levels. It was observed that while live weight, blood serum total protein, blood serum potassium, chloride, and sodium levels decreased $(\mathrm{P}<0.05)$, blood urea and number of rumen protozoa increased $(\mathrm{P}<0.05)$. Considering the values obtained before and after the test, the use of humic acid increased the number of rumen protozoa without negatively affecting blood parameters.
\end{abstract}

Keywords: Blood metabolites, humic acid, lamps, protozoa

\section{Humik Asit Kullanımının Norduz Kuzularında Bazı Kan Parametreleri ile Rumen Protozoaları Üzerine Etkisi}

ÖZET: Bu araştırmada, humik asidin farklı düzeylerinin Norduz kuzularının bazı rumen ve kan parametreleri ile rumen protozoonları üzerindeki etkileri incelendi. Deneme üç faktörlü olarak ölçümlü varyans analizi yapılacak şekilde planlandı ve yürütüldü. Denemede sütten kesilmiş, yaklaşık 16 haftalık yaşta 4 adet Norduz dişi kuzu kullanıldı. Kontrol gribini oluşturan birinci gruptaki kuzulara humik asit verilmedi (GI kontrol), ikinci grupta CA'ın $\% 0.015$ düzeyinde humik asit (GII), üçüncü grupta CA'ın \% 0.030 düzeyinde humik asit, (GIII), dördüncü gruba ise \% 0.060 'i düzeyinde humik asit (GIV) verilecek şeklinde dört grubu yemleme oluşturuldu. Her grupta yaklaşık aynı yaşta ve canlı ağırlıkta $(40.230 \pm 1.25)$ sekiz hayvan olacak şekilde kuzular gruplara rasgele dağıtılmıştır. Kuzuların tükettikleri yem miktarı canlı ağırlıklarının \% 2.5i olarak sınırlanmıştır. Kan ve rumen sıvısı örnekleri, biri deneme başlangıcında biri de denemenin 25. gününde olmak üzere 2 defa alınmıştır. Hayvanlardan deneme öncesinde elde edilen kan parametrelerinin sonuçları deneme sonradaki değerlerle karşılaştırıldığında kan serum trigliserit ve rumen $\mathrm{pH}$ düzeylerinde gözlenmemiștir. Hayvanlarda canlı ağırlık, kan serumu total protein, kan serum potasyum, klor ve sodyum düzeyinde azalma gözlenirken $(\mathrm{P}<0.05)$, kan üre ve rumen protozoa sayısında artma gözlenmiştir $(\mathrm{P}<0.05)$. Araştırmanın sonucunda dönemler dikkate alındığında humik asit kullanımının kan parametreleri üzerinde olumsuz bir etki yapmada rumen protozoa sayısını artırdığı gözlenmiştir.

Anahtar Kelimeler: Humik asit, kan parametreleri, kuzu rumen, protozoonları

Yüzüncü Yıl Üniversitesi, Ziraat Fakültesi, Zootekni Bölümü, Van, Türkiye

Sorumlu Yazar/Corresponding Author: Cemal BUDAĞ, cemalbudag@yyu.edu.tr 


\section{INTRODUCTION}

Humic acids increased absorption of minerals in intestinal wall. As a result, bone mineralization is reported to increase in animals (Mosley, 1996; Tunç, 2007). Humates are known to prevent the development of some hazardous bacteria and stimulate bacterial growth (Riede et al., 1991). The use of humate in dairy goat decreased mastitis cases (Mosley, 1996). Humates have positive effects on immune system of animals. In addition to strengthening the resistance of the animals against pathogens like E.coli, they significantly reduce digestive disorders like diarrhea and others (Humin and Laub, 1998). Lotosh (1991) reported that humates were the drugs which increased resistance to diseases by positively enhancing general health system (Tunç, 2007). Findings of various studies using humates revealed that use of humate promoted growth, positively affected carcass efficiency, enhanced feed efficiency, and reduced instantaneous death rate (Stepchenko et al.. 1991; Yörük et al., 2004; Karaoğlu et al., 2005). It was gointed out that humates increased milk and milk fat amount in dairy cattle, improved live weight increase in livestock, and also decreased temperature stress (Livestock, 2003). Humic acid also helps to prevent excessive loss of water by enhancing water absorption from intestinal lumen (Humin and Eaub, 1998). Similarly, the use of humates was observed to increase live weight gain both in male and female lambs (Teravita, 2004). Adding humate to ratios positively affects feed efficiency and digestive system (Humin and Eaub, 1998). Studies using humic acid reported that humic acids prevented the growth of pathogen bacteria and decreased mycotoxin level (Humin and Laub, 1998; Tunç 2007). Humic acid stimulates neutrophil activity and protects against bacterial agents (Dabovich et al., 2003). Supporting protective epithelial tissue in digestive tract, humates increase resistance to toxins and infections (Kühnert et al., 1991). Previous studies reported that humates had positive effects on lipid metabolism (Stepchenko et al., 1991; Bailey et al., 1996) and might be used in treatment of lipid metabolism disorders (Banaszkiewicz and Drohnik, 1994). It was reported that blood serum total cholesterol, total lipid and glucose levels decreased in rats fed with humate-added feed; whereas, lipoprotein, globulin, hemoglobin, hematocrit value and erythrocyte number increased (Banaszkievicz and Drobnik, 1994; Tunç, 2007). A literature review showed that there was only a limited body of research in Turkish or in foreign languages on effect of humic acid added into ruminant ratios on number of rumen protozoa. Only one study conducted in Turkey was found in literature (Tunç, 2007). The study showed that protozoa were not compulsory for rumen fermentation. However, many studies reported that protozoa increased digestibility capacities of some ratios, daily live weight gain of animals and retention of nitrogen in the body for a longer time and were effective in increasing ammoniac and volatile fatty acids in the rumen. Having proteolytic characteristics, protozoa are known to break down bacteria in addition to feed proteins. In the presence of ciliata in the rumen, ammoniac and volatile fatty acids increase and protozoa with high biological value is synthesized (Coleman, 1986).

Sodium is major intracellular cation and its intra-erythrocyte density is approximately 23 times higher than plasma (Turgut, 2000; Vakit, 2008). While totally $80 \%$ of phosphor in the body is found in bones and teeth in the form of inorganic salts, $20 \%$ is found in soft tissues. Normal serum phosphorus concentration is $1.6-2.4$ mmol-L. $75 \%$ of potassium is found in muscles and less than $2 \%$ found in extracellular fluids. In sheep, normal serum potassium concentration is $4.0-6.0 \mathrm{mEq}-\mathrm{L}$ (Turgut, 2000; Vakit, 2008). Chloride is the main anion in intercellular fluid and blood plasma. Chloride particularly functions in the formation of osmotic pressure as an electrolyte. The normal serum $\mathrm{Cl}$ level in plasma $\mathrm{Cl}$ concentration is $98-115 \mathrm{mEq}-\mathrm{L}$ (Turgut, 2000; Vakit, 2008). Sodium is the largest cation of extracellular fluid. It constitutes $90 \%$ of 154 mols of inorganic cation in each liter of plasma fluid. For this reason, it is responsible for the half of plasma osmolality. In cases of diarrhea, excessive perspiration, and excessive loss of blood and renal infections, $\mathrm{Na}$ concentrations might increase. Normal serum Na density in sheep is $136-154 \mathrm{mEq}-\mathrm{L}$ (Turgut, 2000). The use of humic acid is known to increase oxygen carrying capacity by increasing red blood cells and hemoglobin count, thus arousing the feeling of liveliness to the organism (Malinowska et al., 1993). 


\section{MATERIAL AND METHOD}

\section{Material}

Animal Material: Totally 24, 0.5 year old Norduz sheep were used in the experiment. The data used in statistical analyses were collected from these 24 animals before and after the experiment. The sheep were supplied from sheep raising unit of Yüzüncü Y1l University research and application farm. Feed material: Dry meadow was used as the main feed material.

Table 1. Daily ration feed of the sheep in the trial

\begin{tabular}{cc}
\hline Feedstuff & $\%$ \\
\hline Barley & 40.000 \\
\hline Wheat Bran & 10.000 \\
\hline Soybean meal & 20.000 \\
\hline Sunflower seed meal & 20.000 \\
\hline Salt & 1.000 \\
\hline Marble dust & 2.500 \\
\hline Vitamins + Minerals & 0.500 \\
\hline Energy kcal/kg ME* & 2690 \\
\hline
\end{tabular}

Table 2. The concentrate in the ration

\begin{tabular}{cc}
\hline Feedstuff & Dry matter $\%$ \\
\hline Meadow & 80 \\
\hline Concentrate & 20 \\
\hline
\end{tabular}

A commercially available humic acid called as AGROHUM was used as humic acid. Tables 2.3. and 2.4 illustrate the content of the used humic acid.

Table 3. Chemical composition and properties of the humic acid

\begin{tabular}{cc}
\hline Properties & Rates \\
\hline Humidity & $75 \pm 10 \%$ \\
\hline Total organic matter & $71 \pm 5 \%$ \\
\hline Trace elements & $85 \%$ \\
\hline Soil minerals (SiO2, Al) & $3 \%$ \\
\hline $\mathrm{pH}$ & 7 \\
\hline Electron Capacity. & $2.5 \mathrm{dS} / \mathrm{m} \pm 0.5$ \\
\hline $\mathrm{C} / \mathrm{N}$ & $17 \pm 1$ \\
\hline Size & $0-3 \mathrm{~mm}$ \\
\hline Resolution (in 1\% KOH solution) & very high
\end{tabular}

Table 4. Elemental composition of the humic

\begin{tabular}{cc}
\hline Element & Amount $\%$ \\
\hline Hydrogen $(\mathrm{H})$ & 31.0 \\
\hline Carbon $(\mathrm{C})$ & 3.2 \\
\hline Oxygen $(0)$ & 33.0 \\
\hline Sulfur $(\mathrm{S})$ & 1.7 \\
\hline Nitrogen $(\mathrm{N})$ & 1.8 \\
\hline Phosphorus $(\mathrm{P})$ & 0.5 \\
\hline Potassium $(\mathrm{K})$ & 0.7 \\
\hline Iron $(\mathrm{Fe})$ & 0.9 \\
\hline Calcium $(\mathrm{Ca})$ & 0.5 \\
\hline Magnesium $(\mathrm{Mg})$ & 0.1 \\
\hline
\end{tabular}

\section{Method}

Feeding method: The first group was not given humic acid (control GI); the second group was given humic acid of $0.015 \%$ of the live weights of the sheep (G II); the third group was given humic acid of $0.030 \%$ of the live weights of the sheep (G III); the fourth group was given humic acid of $0.060 \%$ of the live weights of the sheep (GIV). Humic acid was given to the animals by being mixed in 0.51 water for 25 days at the same hour each day. The feed consumed by the animals was restricted to $2.5 \%$ of their live weights.

Table 5. Humic acid administered to the animals (g)

\begin{tabular}{cccc}
\hline GI & GII & GIII & GIV \\
\hline 0.0 & $6.5 \mathrm{~g}$ & $11.7 \mathrm{~g}$ & $26 \mathrm{~g}$ \\
\hline
\end{tabular}

\section{Blood analysis}

For blood analyses, $10 \mathrm{ml}$ blood was collected from vena jugularis of each animal for two times (before and after the test) by using blood collection cannula. Blood samples were centrifuged at $4000 \mathrm{rev} / \mathrm{min}$ and after collecting serum, they were sent to Yüzüncü Y1l University Faculty of Medicine, Biochemistry and Physiology Laboratory. Urea, BUN, total protein, triglyceride, VLDL, Na, K, P, CL, HDL and LDL amounts were analyzed in serum samples. Tokyo/Japan origin modular type Hitachi Automatic Analyzer device and Roche kits were used for blood analyses (Henry, 1965; Ersoy and Bayşu, 1981; Christian and Feldman, 1982). 


\section{Rumen pH analysis}

$50 \mathrm{ml}$ rumen content was collected from each animal using rumen sound two times (before and after the test). $\mathrm{pH}$ of the collected rumen contents was immediately measured by using a digital $\mathrm{pH}$ meter (Dado and Alien, 1993; Vakit, 2008).

\section{Protozoa counting method}

For protozoa counting, rumen content was put into a plastic bottle by using rumen sound. Like in blood sample collection, rumen fluid was collected at the same hour of the day before and after the test. $5 \mathrm{ml}$ of rumen content was separated to achieve stability of the collected rumen content. $15 \mathrm{ml}$ fixing solution (1 1t ethyl alcohol, $5 \mathrm{~g}$ pure NaCI, $0.3 \mathrm{~g}$ methyl grin) was added to the sample. The samples were kept at a cold and dark place until counting. For protozoa counting, $0.05 \mathrm{ml}$ of the sample was placed in Thoma slide following homogenization. Lamella was placed on the slide in such a way to create no air bubble. Counting was conducted by using a standard microscope, with $104 \times 40$ magnification with the help of a camera and screen. Count of protozoa was calculated by using the following formula. Density (mm3) number of counted protozoa, number of counted small squares volume of one small square dilution ratio (Ülker, 2007).

\section{Statistical analyses}

Descriptive statistics of the properties were expressed as means and standard error. To determine if there were differences between the application groups (GI, GII, GIII, GIV) and times (before the test-after the test), Two-Way ANOVA with repeated measurement at one factor level was used. Tukey multiple comparison test was used to determine means of different groups after the analysis of variance.

In factors for which the difference between the means was significant, Group x Time interaction was found to be statistically significant; therefore, Tukey multiple comparison test was used in the level of subgroups. All statistical analyses were performed by using STATISTICA statistical package program (Winer 1971).

\section{RESULTS AND DISCUSSION}

This study was conducted to determine the effects of humic acid on rumen protozoa and blood parameters. Descriptive data obtained from statistical analysis of the collected data are summarized in the following tables. Data obtained from the tests are shown in Tables 6, 7 and 8 .

Table 6. Mean values of live body weights $(\mathrm{kg})$ of the groups before and after the test and standard error $(\mathrm{Mean} \pm \mathrm{SE})$.

\begin{tabular}{|c|c|c|c|c|c|}
\hline & & GI & GII & GIII & GIV \\
\hline & & Mean \pm SE & Mean \pm SE & Mean \pm SE & Mean \pm SE \\
\hline \multirow{2}{*}{$\begin{array}{l}\text { Live body } \\
\text { weight }\end{array}$} & $\mathrm{BT}^{*}$ & $39.40 \pm 1.88 \#$ & $41.73 \pm 1.00 \#$ & $38.43 \pm 1.28 \#$ & $41.37 \pm 0.84 \#$ \\
\hline & $\mathrm{AT}^{*}$ & $34.88 \pm 1.82$ & $36.73 \pm 1.21$ & $33.90 \pm 0.91$ & $35.57 \pm 1.16$ \\
\hline
\end{tabular}

\# Shows the difference between the same group (in the same column) before and after the test $(\mathrm{p}>0.05)$ *BT, AT before and after the test

Table 7. Mean values of total protein, triglyceride and urea of the groups before and after the test and standard error (Mean \pm SE).

\begin{tabular}{cccccc}
\hline & & GI & GII & GIII & GIV \\
\cline { 2 - 6 } & & Mean \pm SE & Mean \pm SE & Mean \pm SE & Mean \pm SE \\
\hline $\begin{array}{c}\text { Total Protein (g } \\
\text { dL-1) }\end{array}$ & BT & $8.10 \pm 0.36 \#$ & $6.58 \pm 0.70$ & $8.62 \pm 0.499 \#$ & $8.28 \pm 0.28 \#$ \\
\cline { 2 - 6 } & AT & $5.83 \pm 0.53 \mathrm{~b}$ & $6.89 \pm 0.16$ & $6.39 \pm 0.26 \mathrm{ab}$ & $5.89 \pm 0.39 \mathrm{~b}$ \\
\hline $\begin{array}{c}\text { Triglyceride (mg } \\
\text { dL-1) }\end{array}$ & BT & $29.5 \pm 0.53$ & $21.35 \pm 0.69$ & $30.34 \pm 0.70$ & $29.91 \pm 0.65$ \\
\cline { 2 - 6 } & AT & $25.67 \pm 0.08$ & $23.43 \pm 0.07$ & $30.20 \pm 0.87$ & $35.71 \pm 0.17$ \\
\hline \multirow{2}{*}{\begin{tabular}{c} 
Urea (mg dL-1) \\
\cline { 2 - 6 }
\end{tabular}} & BT & $20.20 \pm 0.75$ & $16.86 \pm 0.60$ & $20.73 \pm 0.75$ & $15.33 \pm 1.89 \#$ \\
\hline
\end{tabular}

\# Shows the difference between the same group (in the same column) before and after the test $(\mathrm{p}>0.05)$ $a b$ Shows the difference between the same time groups (in the same line) in the same time $(p>0.05)$ 
Table 8. Phosphorus, potassium, chloride and sodium mean values of the groups before and after the test and standard error (Mean \pm SE)

\begin{tabular}{cccccc}
\hline & & GI & GII & GIII & GIV \\
\cline { 2 - 6 } & & Mean \pm SE & Mean \pm SE & Mean \pm SE & Mean \pm SE \\
\hline $\begin{array}{c}\text { Phosphorus (mg } \\
\text { dL-1) }\end{array}$ & BT & $6.77 \pm 0.37 \#$ & $6.70 \pm 0.28$ & $6.24 \pm 0.33$ & $6.95 \pm 0.48$ \\
\cline { 2 - 6 } & AT & $5.61 \pm 0.40$ & $24.44 \pm 0.91$ & $5.30 \pm 0.43$ & $5.89 \pm 0.42$ \\
\hline $\begin{array}{c}\text { Potassium (mmol } \\
\text { dL-1) }\end{array}$ & BT & $5.90 \pm 0.40 \mathrm{ab}$ & $4.03 \pm 0.76 \mathrm{~b}$ & $5.93 \pm 0.25 \mathrm{ab} \#$ & $6.52 \pm 0.54 \mathrm{a}$ \\
\cline { 2 - 6 } & AT & $5.06 \pm 0.78$ & $3.21 \pm 0.39$ & $3.70 \pm 0.87$ & $6.33 \pm 0.31$ \\
\hline $\begin{array}{c}\text { Chloride (mmol } \\
\text { dL-1) }\end{array}$ & BT & $121.67 \pm 5.19 \mathrm{ab \#}$ & $105.80 \pm 17.97 \mathrm{~b}$ & $136.50 \pm 4.75 \mathrm{a} \#$ & $138.67 \pm 8.12 \mathrm{a} \#$ \\
\hline & AT & $96.00 \pm 11.90 \mathrm{~b}$ & $96.97 \pm 18.14 \mathrm{~b}$ & $136.50 \pm 4.75 \mathrm{~b}$ & $138.67 \pm 8.12 \mathrm{ab}$ \\
\hline $\begin{array}{c}\text { Calcium (mmol } \\
\text { dL-1) }\end{array}$ & BT & $165.18 \pm 0.44$ & $147.40 \pm 4.27$ & $182 . \pm 6.11 \#$ & $184.50 \pm 8.84 \#$ \\
\cline { 2 - 6 } & AT & $132.33 \pm 0.45$ & $131.67 \pm 5.06$ & $111.67 \pm 5.72$ & $157.67 \pm 4.37$ \\
\hline
\end{tabular}

\# Shows the difference between the same group (in the same column) before and after the test $(\mathrm{p}>0.05)$

ab Shows the difference between the same time groups (in the same line) in the same time ( $p>0.05)$

Table 9. Phosphorus, potassium, chloride and sodium mean values of the group before and after the test and standard error (Mean \pm SE).

\begin{tabular}{cccccc}
\hline & & GI & GII & GIII & GIV \\
\hline & & Mean \pm SE & Mean \pm SE & Mean \pm SE & Mean \pm SE \\
\hline pH & BT & $7.01 \pm 0.08 \#$ & $6.94 \pm 0.21$ & $6.98 \pm 0.01$ & $7.01 \pm 0.01$ \\
\hline AT & $6.38 \pm 0.20$ & $7.18 \pm 0.18$ & $6.49 \pm 0.27$ & $6.42 \pm 0.15$ \\
\hline & BT & $2692.5 \pm 223.5 \mathrm{~b}$ & $2984.38 \pm 140.9 \mathrm{ab}$ & $2620.0 \pm 67.4 \mathrm{\# b}$ & $3333.5 \pm 223.5 \# \mathrm{a}$ \\
\hline & AT & $3312.5 \pm 152.7 \mathrm{c}$ & $6286.3 \pm 403.4 \mathrm{a}$ & $6081.3 \pm 202.4 \mathrm{a}$ & $5270.6 \pm 152.7 \mathrm{~b}$ \\
\hline
\end{tabular}

\# Shows the difference between the same group (in the same column) before and after the test $(\mathrm{p}>0.05)$

ab Shows the difference between the same time groups (in the same line) in the same time ( $p>0.05)$

It was found that live weights decreased in all groups at the end of the test $(\mathrm{p}<0.05)$. It was thought that this weight loss may be explained from the lowquality meadow hay used as experimental feed and the restriction of consumed feed by each animal with $3 \%$ of their live weights.

It was considered that the decrease in total protein level observed in blood serum before and after the test was associated with the decrease of live weight. However, it was observed that in the second and third groups, blood total protein decreased due to use of humic acid $(p<0.05)$. Blood serum urea level increased in the fourth group compared to the other groups $(p<0.05)$. It was thought that this resulted from the breakdown of tissue proteins as a result of live weight loss. A statistically insignificant increase was observed in blood urea level in all groups. As a consequence these results like to findings to Tunç and Yörük’s study (2012).
Analysis of blood phosphor, potassium, chloride and sodium values showed that the use of humic acid decreased sodium, chloride, and potassium levels in different groups $(\mathrm{p}<0.05)$. The use of humic acid decreased sodium value to normal levels which was above normal limits before the test. However, Tunç and Yörük (2012) found no difference in these parameters. No salt was given to the sheep during the test. Despite the insignificant decrease in the control group, a sharp decrease of sodium observed in humic acid groups might show that humic acid functioned to stabilize sodium. Decreased chloride level observed in blood levels of the animals which were not given salt $(p<0.05)$ could be interpreted like the case in sodium (GIV). There was no difference between the groups in terms of blood phosphorus level and the values were within normal limits (Tunç and Yörük, 2012). The fourth group had an increase in blood serum urea levels in question compared to the other groups ( $p<0.05$ ). 
It was observed that the use of humic acid, which did not have any effect on rumen $\mathrm{pH}$, increased number of rumen protozoa in all three doses unlike Tunç and Yörük's (2012) results $(p<0.05)$. Considering the used humic acid doses, it was found that number of protozoa was the highest in the first group (the lowest dose level).

In this test during which low-quality meadow hay was used, it was observed that different doses of humic acid did not have a negative effect on blood parameters and similarly did not create a negative effect (Tunç and Yörük, 2012) on rumen $\mathrm{pH}(\mathrm{p}<0.05)$. However, it was found that the use of humic acid significantly increased number of rumen protozoa $(p<0.05)$. It is known that the increase in number of protozoa is important and it enhances nitrogen retention in the body of the animals. In conclusion, it can be asserted that the use of humic acid increases the number of protozoa. However, effects of humic acid on serum can be analyzed by future studies.

\section{REFERENCES}

Bailey CA, White KE, Donke SL, 1996. Evaluation of menefee humate $^{\mathrm{tm}}$ on the performance of broilers. B. Poult. Sci. 1996: 75(Suppl. 1): 84 (Abstr.).

Banaszkiewicz W, Drohnik M, 1994. The influence of natural peat and isolated humic acid solution on certain indices of metabolism and of acid-base equilibrium in experimental animals (In Polish). Roczinki Panst Wowego Zakudu Higieny 45:353-360.

Christian, GO, Feldman, V, 1982. The analysis of Copper, Zine, Ealeium, Magnesium, Sodium and Potassium in 111000 Plasma or Serum by Atomie Absorption Spcetrophotometry. Atomie Absorption Speetroseopy; Applieations in Agrieulture, Biology and Medicine. Wiley Interscience, London.

Coleman, GS, 1986. The metabolism of the rumen ciliate protozoa. FEMS Microbiol. Rev.39: 321-344.

Dabovich LA, Hulbert L, Rudine A, Kim E, McGlone JJ, 2003. Evaluation of Nutriceutical Effects on Pig Immunity: Effects of Promox. 2003 Southern Section ASAS Meeting. Pork Industry Institute. Department of Animal and Food Science, TexasTech University. Luhhock TX 79409.

Dado RG, Allen MS, 1993. Continuous computer acquisition of feed and water intakes, Chewing, Reticular Motility and Rumen pH of Cattle. J. Dairy Sci. 76:1589-1600.

Ersoy E, Bayşu M, 1981. "Pratik Biyokimya”. AÜ Vet Fak Yay:372., A.U. Basını Evi, Ankara.

Henry RJ, 1965. "Clinical Chemistry” Harper and Row .. 267, New York
Humin Tech, Huniinfeed-Tierfutterzustze and Laub R. 1998., Acute Systemic Toxicity Studies of Ve t e r in a r y Medicine and Huminsaure Basierende Produkte. Humintech ${ }^{\circledR}$ Humintech GmbH, Heerdter Landstr. 189/D. D-40549 Düsseldorf. Germany, 2004.

Karaoğlu M, Macit M, Esenbuğa N, Turgut L, Aksakal N, Yörük MA, 2005. Morkaraman Kuzularında Bovifarnı'ın Performans Üzerine Etkisi. 111. Ulusal Hayvan Besleme Kongresi 7-10 Eylül Bildiriler Kitabı. Adana 2005: 425-428.

Kühnert VM, Bartels KP, Kröll S, Lange N, 1991. Huminsäurehaltige Tierarzneimittel in Therapie and Prophylaxe bei Gastrointestinalen Erkrankungen von Hund und Katze. Monatshefte Vet. Med., 46: 4-8.

Laub R, 1998b. The chemically induced inhibition of HSV infection. Laub BioChem Corp., August 1998. www.laubiochem.com http://www.laubiochem.com/ (Erişim tarihi: 10 Ağustos 2015)

Livestock R, 2003. Field Trials on Dairy Cattle. Enviromate Mc. 8571 Boat. US 2003

Lotosh TD, 1991. Experimental bases and prospects for the use of humik acid preparations from peat in medicine and agricultural production. Nauchne Doki Vyss Shkoi Biol. Nauki 1991: 10: 99- 103

Malinowska $\mathrm{MH}$, Pietraszek D, Chabielska E, 1993. Acta Pol. Pharm. 1993:50:507-511. Mosley R., 1996. Field Trials of Dairy Cattle. No published Research. Enviromate Inc. August 1996

Riede UN, Zeck-Kapp G, Freudenberg N, Keller HU, Scuhert B, 1996. Humat induced activation of human granulocytes. Virchows Arch B Cell Pathol Inc. Mol. Pathol. 996: 60: 27-34.

Tunç A, 2007. Humatların korunlarda rumen parametreleri ve bazı kan değerleri üzerine etkisi. (Doktora Tezi) Atatürk Üniversitesi Sağlık Bilimleri Enstitüsü Hayvan besleme ve Beslenme Hastalıkları Anabilim Dalı Erzurum.

Stepchenko LM, Zhorina LV, Kravtsova LV, 1991. The effect of sodium humat on metabolism and resistance in highly productive poultry. Nauchnye Doki Vyss Shkoly Biol. Mauki 1991 10: 90-95.

Yörük MA, Gül M, Hayırlı A, Macit M, 2004. The effects of supplementation of humat and prophetic on egg production and quality parameters during the late laying period in hens. Pouhry Sci. 2004: 83: 84-88.

Teravita U, 2004. Hamates in Poultry and Stock Farming. http:// www.teravita.com/Humates/Chapter9.htm (Erişim tarihi: 15 Ağustos 2015).

Tunç MA, Yörük MA, 2012. Humik asítierín koyuntarda rumen ve kan parametreleri ile protozoon sayısı üzerine etkisi . Kafkas Univ Vet Fak Derg 18(1): 55-60, 2012.

Turgut K, 2000.Veteriner Klinik Laboratuvar Teşhis, Selçuk Üniv., Veteriner Fak., Konya. 920 s.

Ülker H, 2007 Ders Notları. Yüzüncü Yıl Üniversitesi Ziraat Fakültesi Zootekni Bölümü Van. Vakit S, 2008 Mürdümük tane yem mm norduz kuzularında bazı rumen ve kan parametreleri ile rumen protozoonları üzerine etkisi. YYÜ Fen Bilimleri Enstitüsü (basılmamış yüksek lisans tezi). Van. 